\title{
Interrelationships between Height and Selected Linear Body Dimensions and Estimation of Sex in Nepali-Speaking Adults from Naxalbari, Darjeeling
}

\section{Sudip Datta Banik}

Department of Human Ecology, Cinvestav-IPN, Merida, Yucatan, Mexico

*Corresponding author: Sudip Datta Banik, Department of Human Ecology, Centre for Research and Advanced Studies (Cinvestav) IPN, Merida, Yucatan, Mexico, Tel: +52-999-1135456; E-mail: dattabanik@cinvestav.mx

Received date: October 04, 2016; Accepted date: November 24, 2016; Published date: November 28, 2016

Copyright: ( 2016 Datta Banik S. This is an open-access article distributed under the terms of the Creative Commons Attribution License, which permits unrestricted use, distribution, and reproduction in any medium, provided the original author and source are credited.

\begin{abstract}
Background: Several reports are available on human body dimensions (BD), their interrelationships with height, sex difference and sex estimation from different populations.
\end{abstract}

Objectives: To understand interrelationships between linear BD and height in adults and estimation of sex.

Methods: A sample of 20-39 years old Nepali-speaking 268 adults (158 men, 110 women) was selected from Naxalbari in Darjeeling, West Bengal, India. Anthropometric measurements included height, sitting height (SH), upper arm length (UAL), forearm length (FAL), combined length of forearm and hand (CLFH), total arm lengths (TAL) (left side), hands and feet (bilateral length and breadth). Sub-ischial leg length (SLL) and indices (hands and feet), relative proportion, multiplication factors (MF) of linear BD for height were calculated. Sectioning point (SP) values [(mean value in men + mean value in women $) / 2]$ were calculated for anthropometric variables to estimate sex.

Results: The SH and SLL each shared almost $50 \%$ of height. Relative proportions of BD to height were: TAL (men $45.39 \%$, women $46.36 \%$ ), CLFH (men 25.88\%, women 26.58\%), UAL (men 19.48\%, women 19.82\%) and FAL (men $14.83 \%$, women 15.47\%). Foot length (FL) and hand length (HL) was approximately $15 \%$ and $11 \%$ of height in men and women respectively. Foot breadth (FB) and hand breadth (HB) were approximately $6 \%$ and $5 \%$ of height respectively. The approximate values of MF of BD for height were calculated for TAL (2), CLFH (4), UAL (5), FAL and foot length (7), HL (9), FB (17), and HB (20). Based on SP value, sex estimation was done accurately (\%) for SH (82.10\%), FL (bilateral 81.72\%), HL and FB (left 79.10\%), FB (right $77.99 \%$ ), HB (right $77.61 \%$ ), TAL, HL (right) and HB (left) (75.37\%), SLL (74.25\%), CLFH (70.15\%), UAL (66.67\%) and FAL (62.70\%).

Conclusion: The MF and SP values were effective in understanding relative proportions of BD to height and sex estimation respectively.

Keywords: Multiplication factor; Sectioning point; Sex estimation; Height; Arm; Hand; Foot; Leg length

Abbreviations: BD: Body Dimensions; CLFH: Combined Length of Forearm and Hand, FAL: Forearm Length; FB: Foot Breadth; FL: Foot Length; HB: Hand Breadth; HL: Hand Length; SH: Sitting Height; SLL: Sub-ischial Leg Length; SP: Sectioning Point; TAL: Total Arm Length; UAL: Upper Arm Length

\section{Introduction}

In medico-legal practices and criminalistics, estimation of sex from height and body proportions is an important work. Stature or height as a structural morphological feature has established relationships of different degrees with other body dimensions in adult humans. Height estimation from the measurements of different body dimensions, particularly upper and lower extremities are quite age-old investigations over centuries [1]. Studies representing several communities from India and other countries, particularly on percutaneous measurements of upper and lower extremities, hands and feet in adults were done to estimate height, based on either regression analysis or multiplication factor and also to measure sex differences. To cite a few from India, studies were done among Gaur Brahmins of Punjab [2], Jats of Rajasthan [3], Punjabis of Delhi [4], Rajputs of Pauri Garhwal [5], Rajputs of Dehradun [6], Thais of Assam [7], Brahmins of Kumaon [8,9], Gujjars of North India [10-12], Rajbanshis of West Bengal [13] and others [14-28]. Use of hand and foot dimensions to estimate height are also reported from other countries including Egypt [29], Mauritius [30-32], Nigeria [33-35], Sri Lanka [36], Turkey [37-39] and the US Army [40]. Previous studies on height estimation from percutaneous measurements of upper and lower limbs are reported from India [41-45]. Studies on prediction of height from upper and lower limbs are also reported from other countries including Iran [46], Sudan [47] and others [48-50]. There are some other studies that reported estimation of sex from hand and foot dimensions [19,51-54]. However, reports on estimation of sex from linear body dimensions including upper and lower limbs are not available, at least from eastern India that raised my interest in the present research. Therefore, it was important to report the interrelationships between height and linear body dimensions and also sex difference and estimation, using some simple methods that could 
be useful in research in the areas of human biology and forensic sciences.

In this background, the present study was done in a sample of 20 years to 39 years old 268 adults (158 men, 110 women) from Naxalbari in Darjeeling, West Bengal. The objectives of the study were:

- To observe sexual dimorphism with respect to height and selected linear body dimensions (sitting height, sub-ischial leg length, upper arm, fore arm and total arm lengths, hands and feet length and breadth) in the sample of adults.

- To find interrelationships between height and body dimensions based on proportion (\%) and multiplication factor.

- To estimate sex, using sectioning point value for height and linear body dimensions and to record the agreements of such estimation with actual classification in men and women.

\section{Participants and Methods}

The present study was descriptive cross-sectional in nature, carried out on household survey basis during 2008-2012. Data collection was done in connection with two research projects. A probabilistic sample [55] of 268 adult individuals ( 158 men and 110 women) aged 20 years to 39 years was drawn from seven villages of Naxalbari region in Darjeeling district of West Bengal, an eastern regional state of India. Naxalbari, a community development block (an official jurisdiction) was located around $35 \mathrm{~km}$ from Siliguri sub-divisional town in Darjeeling, which was approximately $580 \mathrm{~km}$ towards north from Kolkata (previously known as Calcutta), the provincial capital of the State. The participants were primarily Nepali language speaking adults representing Dhimal, Limbu, Mech, and Rai endogamous communities who lived in those villages. Based on total population size with proportional representation of adult individuals by age group (20 years to 39 years) from villages under Naxalbari region (men=170, women $=150$, according to the voter's list prepared by the Election Commission, Government of India and available at the local block development office), the sample of 268 individuals was obtained with 95\% CI (confidence intervals) and 5\% margin of error. Some adult men $(n=39)$ had shown their interest to participate in the survey and were included.

The communities (Dhimal, Limbu, Mech, and Rai) in the region are Tibeto-Burman language speaking groups and have a common ethno history of origin [56]. However, presently they differ in socio-economic characteristics [57-59]. Dhimal community is an "Other Backward Class" and three other communities (Limbu, Mech, Rai) are the Scheduled Tribes in Government registers. Primary occupation of these community people was agriculture. People from Limbu and Rai communities were also engaged in Government jobs. In addition, some people had their own business in the locality (selling areca nuts, having small shops etc.).

Ethical approval was obtained from the appropriate authorities of the University before the commencement of the study that was a primary requisite of the research projects approved by the agencies. Informed verbal consent was obtained from the community leaders and the participants before recording of data. Measurements were taken by the author and technical errors of measurements were within acceptable limits [60] and thus not incorporated in statistical analyses.

Measurements of height $(\mathrm{cm})$, length $(\mathrm{cm})$ and breadth $(\mathrm{cm})$ of hands and feet and other linear body dimensions (e.g., sitting height, upper arm, forearm, and total arm lengths) $(\mathrm{cm})$ were recorded following standard international protocols [61,62]. Participants had no physical handicap or previous history of trauma-related effects on body dimensions. Measurements of hands and feet (length and breadth) were recorded bilaterally. However, measurements of upper arm length, forearm length, combined length of forearm and hand, and total arm length were taken only one left side. Height, sitting height and foot length were measured using standard Martin's anthropometer; arm lengths were measured using a spreading caliper; linear dimensions of hands (length and breadth) and feet (breadth) were measured using a standard sliding caliper to the nearest tenth of a centimeter.

Upper arm length was measured marking the landmarks acromoin (ac) and radiale (r). The acromion was identified and marked after asking the participant to bend laterally at the trunk to relax deltoid muscle. The radiale was identified by palpating the lateral dimple at the elbow little downward. The combined length of forearm and hand length was measured using the spreading caliper between landmarks: radiale $(r)$ and the most anterior projecting point of the middle finger (dactylion). Forearm length was measured between radiale ( $r$ ) and stylion (sty). Total arm length was the sum of upper arm length and combined length of forearm and hand. Hand and foot dimensions were measured following the method described in earlier studies $[20,21]$. Hand length was measured as a linear distance between the distal crease of the wrist joint (inter-stylion) and dactylion. Hand breadth was measured as a straight distance between the most laterally placed point of the $2^{\text {nd }}$ metacarpal (metacarpal-radiale) to the most medially placed point of the $5^{\text {th }}$ metacarpal of hand (metacarpalulnare). Hand dimensions were measured facing the palmar (ventral) surface. Foot length was measured using the first segment of a standard anthropometer, as the linear distance between the most prominent part of the heel (pternion) to the distal part of the longest toe $\left(2^{\text {nd }}\right.$ or $\left.1^{\text {st }}\right)$ (acropodian). Foot breadth was measured between the most prominent point of the medial side of the foot (metatarsal-tibiale) on the anterior epiphyses of the $1^{\text {st }}$ metatarsal, and the most prominent point of the lateral side (metatarsal-fibulare) on the joint of the anterior epiphyses of the $5^{\text {th }}$ metatarsal. Foot dimensions were measured on the dorsal surface when the participant was standing erect.

Derived variables were calculated as: sub-ischial leg length (height minus sitting height) [64], hand index and foot index [(breadth/length) $\times 100][20,32,35,54]$. Relative proportion of linear body dimensions to height has been figured out by percentage (\%), multiplication factor (ratio of height and body dimension) was calculated. Sectioning point values of anthropometric characteristics and derived variables were the cut-off value to estimate sex [(mean value in men+mean value in women)/2] $[19,52,53,64]$. Sex estimation was done for men with higher values than sectioning point and women were classified below the cutoff value. Data of height and other anthropometric measurements were normally distributed following assumptions (Shapiro-Wilk test, $p>0.05$ ). Student's t-test was performed to test for differences in mean anthropometric characteristics between men and women. Pearson correlation (bivariate) coefficients were computed to evaluate the association between variables. Sex was explained as male $(=1)$ and female $(=2)$ in the database. After estimation of sex using sectioning point cut-off values, sex was also explained in the same way (male $=1$, female $=2)$. Subsequently, frequencies of agreement $(=0$ in male and female) and disagreement [ 1 (absolute $)=$ male and female $]$ of cases were calculated. All statistical analyses were done using the SPSS statistical package (version 13.00). For all statistical tests, $p<0.05$ was taken as the significance level. 
Citation: Datta Banik S (2016) Interrelationships between Height and Selected Linear Body Dimensions and Estimation of Sex in NepaliSpeaking Adults from Naxalbari, Darjeeling. J Forensic Res 7: 354. doi:10.4172/2157-7145.1000354

Page 3 of 8

\section{Results}

Mean age of men and women (range 20 years to 39 years) did not vary significantly $(\mathrm{p}>0.05)$ showing higher mean value in women (33.11 years \pm 8.82 years) than men (32.35 years \pm 7.66 years) (Table 1). Mean values of height and other linear body dimensions were higher in men than women with significant sex difference $(\mathrm{p}<0.001)$. Highest difference of mean value between men and women was observed in height $(14.08 \mathrm{~cm})$, followed by sub-ischial leg length $(7.38$ $\mathrm{cm})$, sitting height $(6.60 \mathrm{~cm})$, arm length (in the order of total, fore and upper arm length), foot length and hand length, foot breadth and hand breadth. Difference of mean values of hand index (bilateral) between men and women was not significant $(\mathrm{p}>0.05)$. However, sex difference was significant $(\mathrm{p}<0.05)$ for foot index (bilaterally) (Table 1$)$. Correlation between height and other anthropometric characteristics was significant $(\mathrm{p}<0.05)$ in men and women except a few characteristics including forearm (in women), combined length of forearm and hand (in women), hand index (in women), and foot index (in men and women) (Table 1).

\begin{tabular}{|c|c|c|c|c|c|c|}
\hline \multirow{2}{*}{ Variables } & Men & Women & \multirow{2}{*}{$\mathbf{t}^{\star *}$} & $\mathrm{p}$-value & \multirow{2}{*}{$\begin{array}{l}\text { Men } \\
\text { r\# }\end{array}$} & \multirow{2}{*}{$\begin{array}{l}\text { Women } \\
\text { r\# }\end{array}$} \\
\hline & Mean (SD)* & Mean (SD) & & & & \\
\hline Age (years) & $32.35(7.66)$ & $33.11(8.82)$ & -0.75 & 0.23 & -0.37 & -0.36 \\
\hline Height $(\mathrm{cm})$ & $161.46(6.22)$ & $147.39(6.54)$ & 17.7 & $<0.001$ & 1 & 1 \\
\hline Sitting height $(\mathrm{cm})$ & 81.25 (3.69) & $74.65(3.43)$ & 15.02 & $<0.001$ & 0.65 & 0.58 \\
\hline Sub-ischial leg length $(\mathrm{cm})$ & $80.11(4.65)$ & $72.73(5.33)$ & 11.74 & $<0.001$ & 0.78 & 0.85 \\
\hline Upper arm length $(\mathrm{cm})$ & $31.44(2.84)$ & $29.19(2.61)$ & 6.69 & $<0.001$ & 0.33 & 0.36 \\
\hline Forearm length $(\mathrm{cm})$ & $23.95(3.34)$ & $22.76(3.09)$ & 3 & 0.003 & 0.32 & 0.04 \\
\hline $\mathrm{CLFH}(\mathrm{cm})$ & $41.79(3.55)$ & $39.12(3.11)$ & 6.51 & $<0.001$ & 0.45 & 0.18 \\
\hline Total arm length $(\mathrm{cm})$ & $73.28(3.67)$ & $68.26(3.92)$ & 10.59 & $<0.001$ & 0.67 & 0.4 \\
\hline Hand length $(\mathrm{cm})$ left & $17.84(0.89)$ & $16.35(0.92)$ & 13.12 & $<0.001$ & 0.56 & 0.49 \\
\hline Hand length $(\mathrm{cm})$ right & $17.76(0.87)$ & $16.44(0.91)$ & 11.94 & $<0.001$ & 0.53 & 0.51 \\
\hline Hand breadth $(\mathrm{cm})$ left & $7.96(0.43)$ & $7.38(0.45)$ & 10.57 & $<0.001$ & 0.3 & 0.36 \\
\hline Hand breadth $(\mathrm{cm})$ right & $8.05(0.45)$ & $7.45(0.44)$ & 10.95 & $<0.001$ & 0.31 & 0.36 \\
\hline Hand index (left) & $44.66(2.24)$ & $45.16(2.60)$ & -1.64 & 0.1 & -0.24 & -0.1 \\
\hline Hand index (right) & $45.38(2.29)$ & $45.35(2.30)$ & 0.12 & 0.91 & -0.17 & -0.13 \\
\hline Foot length $(\mathrm{cm})$ left & $24.70(1.28)$ & $22.61(1.16)$ & 13.92 & $<0.001$ & 0.53 & 0.37 \\
\hline Foot length $(\mathrm{cm})$ right & $24.68(1.26)$ & $22.76(1.05)$ & 13.52 & $<0.001$ & 0.53 & 0.33 \\
\hline Foot breadth $(\mathrm{cm})$ left & $9.63(0.63)$ & $8.62(0.62)$ & 13.04 & $<0.001$ & 0.43 & 0.34 \\
\hline Foot breadth $(\mathrm{cm})$ right & $9.62(0.63)$ & $8.68(0.59)$ & 12.56 & $<0.001$ & 0.4 & 0.41 \\
\hline Foot index (left) & $39.01(2.17)$ & 38.18 (2.65) & 2.73 & 0.01 & 0.01 & 0.07 \\
\hline Foot index (right) & $39.02(2.16)$ & 38.15 (2.49) & 2.94 & 0.01 & -0.03 & 0.2 \\
\hline \multicolumn{2}{|c|}{$\begin{array}{l}\text { *SD: Standard Deviations. } \\
{ }^{* *} \text { Negative signs of } t \text { values indicate higher mean values in women. }\end{array}$} & & & & & \\
\hline
\end{tabular}

Table 1: Descriptive statistics, sex difference of age and anthropometric characteristics and correlation between height and other variables in men $(\mathrm{n}=158)$ and women $(\mathrm{n}=110)$ from Naxalbari, Darjeeling.

Interrelationships between height and linear body dimensions, estimated by relative proportions (\%) and multiplication factors did not show consistent pattern of sex difference (Table 2). Sitting height and sub-ischial leg length values were found to be approximately $51 \%$ and $49 \%$ respectively of total height of an individual with no significant sex difference ( $p>0.05)$. Total arm length as found to be longer in men
(Table 1) but it's proportion to height was higher in women $(46.36 \%)$ than men $(45.39 \%)$ with significant sex difference $(\mathrm{p}<0.05)$. Similar trend was found in forearm length (men $14.83 \%$, women $15.47 \%$ of height), the combined length of forearm and hand (men 25.88\%, women $26.58 \%$ of height) showing significant difference between men and women $(\mathrm{p}<0.05)$. 
Citation: Datta Banik S (2016) Interrelationships between Height and Selected Linear Body Dimensions and Estimation of Sex in NepaliSpeaking Adults from Naxalbari, Darjeeling. J Forensic Res 7: 354. doi:10.4172/2157-7145.1000354

Page 4 of 8

\begin{tabular}{|c|c|c|c|c|}
\hline \multirow[b]{2}{*}{ Variables } & Men & Women & \multirow[b]{2}{*}{$\mathbf{t}^{\star *}$} & \multirow[b]{2}{*}{ p-value } \\
\hline & Mean (SD)* & Mean (SD) & & \\
\hline Sitting height/height percentage & $50.34(1.79)$ & $50.69(2.17)$ & -1.46 & 0.15 \\
\hline Sub-ischial leg length/height percentage & $49.60(1.83)$ & $49.31(2.17)$ & 1.22 & 0.23 \\
\hline Upper arm/height percentage & $19.48(1.69)$ & $19.82(1.70)$ & -1.6 & 0.11 \\
\hline Forearm/height percentage & $14.83(1.98)$ & $15.47(2.20)$ & -2.46 & 0.02 \\
\hline CLFH/height percentage & $25.88(1.99)$ & $26.58(2.27)$ & -2.67 & $<0.01$ \\
\hline Total arm/height percentage & $45.39(1.71)$ & $46.36(2.72)$ & -3.57 & $<0.01$ \\
\hline Hand length left/height percentage & $11.05(0.47)$ & $11.11(0.60)$ & -0.82 & 0.41 \\
\hline Hand length right/height percentage & $11.00(0.48)$ & $11.16(0.58)$ & -2.41 & 0.02 \\
\hline Hand breadth left/height percentage & $4.93(0.28)$ & $5.01(0.32)$ & -2.09 & 0.04 \\
\hline Hand breadth right/height percentage & $4.99(0.29)$ & $5.06(0.31)$ & -1.8 & 0.07 \\
\hline Foot length left/height percentage & $15.30(0.70)$ & $15.36(0.86)$ & -0.6 & 0.55 \\
\hline Foot length right/height percentage & $15.29(0.69)$ & $15.47(0.85)$ & -1.84 & 0.07 \\
\hline Foot breadth left/height percentage & $5.97(0.36)$ & $5.86(0.43)$ & 2.26 & 0.02 \\
\hline Foot breadth right/height percentage & $5.96(0.37)$ & $5.89(0.39)$ & 1.51 & 0.13 \\
\hline Multiplication factor (sitting height for height) & $1.99(0.07)$ & $1.98(0.08)$ & 1.37 & 0.17 \\
\hline Multiplication factor (sub-ischial leg length) & $2.02(0.08)$ & $2.03(0.10)$ & -1.31 & 0.19 \\
\hline Multiplication factor (upper arm) & $5.17(0.45)$ & $5.08(0.44)$ & 1.61 & 0.11 \\
\hline Multiplication factor (forearm) & $6.90(1.25)$ & $6.61(1.06)$ & 2.09 & 0.04 \\
\hline Multiplication factor (CLFH) & $3.89(0.34)$ & $3.79(0.33)$ & 2.4 & 0.02 \\
\hline Multiplication factor (total arm) & $2.21(0.08)$ & $2.16(0.13)$ & 3.27 & $<0.01$ \\
\hline Multiplication factor (hand length left) & $9.06(0.39)$ & $9.03(0.46)$ & 0.68 & 0.5 \\
\hline Multiplication factor (hand length right) & $9.11(0.39)$ & $8.98(0.44)$ & 2.36 & 0.02 \\
\hline Multiplication factor (hand breadth left) & $20.34(1.14)$ & $20.04(1.23)$ & 2.04 & 0.04 \\
\hline Multiplication factor (hand breadth right) & $20.10(1.16)$ & $19.85(1.17)$ & 1.79 & 0.07 \\
\hline Multiplication factor (foot length left) & $6.55(0.35)$ & $6.53(0.35)$ & 0.46 & 0.64 \\
\hline Multiplication factor (foot length right) & $6.55(0.34)$ & $6.48(0.34)$ & 1.65 & 0.1 \\
\hline Multiplication factor (foot breadth left) & $16.82(1.03)$ & $17.17(1.29)$ & -2.43 & 0.02 \\
\hline Multiplication factor (foot breadth right) & $16.84(1.04)$ & $17.05(1.15)$ & -1.57 & 0.12 \\
\hline \multicolumn{5}{|c|}{$\begin{array}{l}\text { *SD: Standard Deviations } \\
\text { **Negative signs of } t \text { values indicate higher mean values in women. Numerals in bold font indicate significant sex difference }(p<0.05) \text {. } \\
\text { CLFH: Combined Length of Forearm and Hand. }\end{array}$} \\
\hline
\end{tabular}

Table 2: Relative proportions and multiplication factors of linear body dimensions to height in men $(\mathrm{n}=158)$ and women $(\mathrm{n}=110)$.

However, no significant sex difference $(p>0.05)$ was observed in the proportion of upper arm length to height (men 19.48\%, women $19.82 \%)$. Foot length (bilateral) was approximately $15 \%$ of height in men and women showing no sexual dimorphism $(\mathrm{p}>0.05)$. Hand length was noted to be approximately $11 \%$ (bilateral) in men and women; significant sex difference was found in right side $(\mathrm{p}<0.05)$ though the difference of mean values was low $(0.16 \mathrm{~cm})$. Foot breadth and hand breadth were approximately $6 \%$ and $5 \%$ of height respectively in men and women with significant sex difference on left side $(\mathrm{p}<0.05)$ (Table 2$)$. 
Citation: Datta Banik S (2016) Interrelationships between Height and Selected Linear Body Dimensions and Estimation of Sex in NepaliSpeaking Adults from Naxalbari, Darjeeling. J Forensic Res 7: 354. doi:10.4172/2157-7145.1000354

Page 5 of 8

Multiplication factor values were in the reverse order of the relative lengths of body dimensions to height (Table 2). Multiplication factor values for sitting height and sub-ischial leg length to height was least, approximately 2 in men and women showing no significant sex difference $(\mathrm{p}>0.05)$. In the increasing order of the approximate values of multiplication factors of body dimensions for height were total arm length (2), combined length of forearm and hand (4), upper arm length (5), forearm length (7), foot length (7), hand length (9), foot breadth (17), and hand breadth (20) in adults. Significant sex difference $(p<0.05)$ was observed in cases of forearm, combined length of forearm and hand, total arm length, hand length (right), hand breadth (left), and foot breadth (left). Men had higher mean multiplication factor values than women except foot breadth (Table 2).

\begin{tabular}{|c|c|c|c|c|c|}
\hline \multirow[b]{2}{*}{ Variables } & \multirow[b]{2}{*}{$\mathbf{S P}^{*}$} & \multirow[b]{2}{*}{ Agreement (\%) } & \multicolumn{3}{|l|}{ SP earlier reports ${ }^{* *}$} \\
\hline & & & $\begin{array}{l}\text { Kanchan and Rastogi [54] } \\
(n=500)\end{array}$ & Krishnan et al. [19] $(n=200)$ & $\begin{array}{l}\text { Dey and Kapoor [53] } \\
(n=182)\end{array}$ \\
\hline Height $(\mathrm{cm})$ & 154.42 & 87.31 & NA & NA & NA \\
\hline Sitting height $(\mathrm{cm})$ & 77.95 & 82.1 & NA & NA & NA \\
\hline Sub-ischial leg length $(\mathrm{cm})$ & 76.42 & 74.25 & NA & NA & NA \\
\hline Upper arm length $(\mathrm{cm})$ & 30.31 & 66.67 & NA & NA & NA \\
\hline Forearm length $(\mathrm{cm})$ & 23.46 & 62.7 & NA & NA & NA \\
\hline $\mathrm{CLFH}(\mathrm{cm})$ & 40.45 & 70.15 & NA & NA & NA \\
\hline Total arm length $(\mathrm{cm})$ & 70.77 & 75.37 & NA & NA & NA \\
\hline Hand length $(\mathrm{cm})$ Left & 17.1 & 79.1 & 17.49 & 18.9 & 18.28 \\
\hline Hand length $(\mathrm{cm})$ Right & 17.1 & 75.37 & 17.54 & 18.9 & 18.39 \\
\hline Hand breadth $(\mathrm{cm})$ Left & 7.67 & 75.37 & 7.71 & 7.5 & 7.82 \\
\hline Hand breadth $(\mathrm{cm})$ Right & 7.75 & 77.61 & 7.83 & 7.6 & 7.94 \\
\hline Hand index (left) & 44.91 & 43.66 & 44.11 & 39.9 & 43 \\
\hline Hand index (right) & 45.36 & 50 & 44.68 & 40.5 & 43.27 \\
\hline Foot length $(\mathrm{cm})$ Left & 23.66 & 81.72 & 23.65 & NA & NA \\
\hline Foot length $(\mathrm{cm})$ Right & 23.72 & 81.72 & 23.68 & NA & NA \\
\hline Foot breadth $(\mathrm{cm})$ Left & 9.12 & 79.1 & 9.05 & NA & NA \\
\hline Foot breadth $(\mathrm{cm})$ Right & 9.15 & 77.99 & 9.12 & NA & NA \\
\hline Foot index (left) & 38.59 & 58.96 & 38.29 & NA & NA \\
\hline Foot index (right) & 38.59 & 55.6 & 38.53 & NA & NA \\
\hline
\end{tabular}

Table 3: Estimation of sex from height and other linear body dimensions using sectioning point values and agreement in classification for men $(\mathrm{n}=158)$ and women $(\mathrm{n}=110)$.

Based on sectioning point value, estimation of sex was done where height (cut-off value $154.42 \mathrm{~cm}$ ) showed highest agreement $(87.31 \%)$ with actual distribution of sex by the individual values of height (Table 3). The decreasing order of correct classification of sex using sectioning point values were sitting height $(82.10 \%)$, foot length (bilateral 81.72\%), hand length and foot breadth (left side 79.10\%), foot breadth (right side $77.99 \%$ ), hand breadth (right $77.61 \%$ ), total arm length, hand length (right) and hand breadth (left) $(75.37 \%)$, sub-ischial leg length $(74.25 \%)$, combined length of forearm and hand (70.15\%), upper arm length (66.67\%) and forearm length (62.70\%). The results show relatively lower rate of agreement of estimation of sex using sectioning point values for hand index and foot index (bilateral).

\section{Discussion}

The sample represented a young adult population from Darjeeling in West Bengal who were predominantly Nepali language speaking. However, people in this region also speak in other languages including Bengali (of the region) and Hindi (national). In addition, people from respective communities also speak in their native languages (Dhimal, 
Limbu, Mech, and Rai). During fieldwork, from the collected sociodemographic information, it was observed that the communities were endogamous and between community marriages were relatively low $(<1 \%)$. To summarize the results of the present study, as expected, significant sex difference $(\mathrm{p}<0.05)$ was observed with respect to the anthropometric characteristics and derived parameters with higher mean values in men. Sitting height and sub-ischial leg lengths were sharing 50\% each of the height vertex. It was interesting to note that in spite of having longer total arm length, men had lower relative length of total arm length to height than women. Significant sexual dimorphism $(\mathrm{p}<0.05)$ for total arm length was due to the significant difference between men and women in the combined length of forearm and hand. Relative lengths for hands and feet to height was similar in both sex. The results of the present study, particularly of hand and foot dimensions (length and breadth) showed similar patterns of sex difference noted in earlier studies as follows.

A study [21] among 17-year-old to 20-year-old Rajputs of Himachal Pradesh, India, on hand and foot dimensions (length and breadth), sex difference was significant $(\mathrm{p}<0.05)$ and the variables estimated height where foot length provided highest reliability and accuracy. Foot dimensions (length and breadth) were used for the estimation of sex, age and stature in a sample of young University students from Delhi, India (age range 18 years to 22 years) [25]. Correlation coefficients between height and foot dimensions were positively significant $(p<0.05)$; foot length in men and foot breadth in women provided highest accuracy to estimate height through regression analysis. Foot dimensions (length and breadth) also predicted height accurately $(p<0.05)$ in a sample of adults from Gujjars in north India [10-12]. Hand and foot lengths showed significant sex difference $(p<0.05)$ and also accurately estimated height in a sample of 19-year-old to 22-yearold young University students from Maharashtra [17].

In a previous study, among Nigerian adults (18 years to 30 years of age), mean values of hand dimensions in men were significantly higher than the values recorded in women (sex difference, $p<0.05$ ) [35]. In the study, mean values of hand length (men: right $19.02 \mathrm{~cm}$ left $19.09 \mathrm{~cm}$; women: right $17.62 \mathrm{~cm}$, left $17.69 \mathrm{~cm}$ ) and hand breadth (men: right $8.58 \mathrm{~cm}$, left $8.43 \mathrm{~cm}$; women: right $7.69 \mathrm{~cm}$, left $7.58 \mathrm{~cm}$ ) of adult Nigerians were higher than men and women in the present study. Significant sex difference $(\mathrm{p}<0.05)$ with respect to height, hand and foot dimensions (length and breadth) were observed in another sample of young adult University students from Zaria, Nigeria where hand and foot dimensions yielded important predictive information for height [34]. Another study among Nigerian adults, men had longer and broader feet than women with significant difference $(p<0.001)$ [33]. In that report, mean values of foot length (men: right and left $26.92 \mathrm{~cm}$; women: right $25.00 \mathrm{~cm}$, left $24.75 \mathrm{~cm}$ ) and foot breadth (men: right $9.87 \mathrm{~cm}$, left $9.75 \mathrm{~cm}$; women: right $9.14 \mathrm{~cm}$, left $8.92 \mathrm{~cm}$ ) of adult Nigerians ( $>18$ years of age) were higher than men and women in the present study.

Multiplication factor values also give us easy way to understand the relative estimate of linear body dimensions for height in men and women as it was observed in the present study. However, regression models were found to be more effective than multiplication factor to estimate height (in both cases, $\mathrm{p}<0.05$ ) from hand and foot dimensions (length and breadth) in a sample of young adults (17 years to 20 years) from north India [20]. Correlation coefficient and predictive value of foot dimensions in regression models for stature were significant $(p<0.05)[10,21,38]$. Hand dimensions correctly predicted height in a sample of adults from Egypt [29]. A study among young students (17 years to 23 years of the Medical Faculty of Cukurova University, Turkey, hand length and hand breadth were highly correlated to height and also predicted height significantly in multiple linear regression models [38]. Another study in adults from Turkey reported foot length and foot width had significant sex difference $(\mathrm{p}<0.05)$; foot dimension had high accuracy to determine sex (right 95.6\%, left 96.4\%) [39]. In Mauritius, in a sample of young University students aged 18 years to 30 years, foot length was recorded to be an efficient predictor for height in curvilinear regression models [31]. In the same sample, hand dimensions (length and breadth) significantly explained height in curvilinear regression models for men and women [30]. Among Sri Lankan adults aged 20 years to 23 years, sex difference with respect to hand length along with correlation between height and hand length were significant $(\mathrm{p}<0.05)$ and height was predicted significantly from hand length through regression analysis [36].

In the present study, sectioning point values for height, sitting height, sub-ischial leg length and bilateral measurements for hand and foot dimensions (length and breadth) accurately estimated sex showing high agreement with original distribution of sex by the individual values of anthropometric characteristics (Table 3). However, hand index and foot index were found to be the poor sex discriminators. The results had similar patterns as reported earlier based on sectioning point values. Foot length and foot breadth (bilateral) showed significant sex difference $(\mathrm{p}<0.05)$ in a studied sample from north India but foot index did not accurately estimate sex [54]. Bilateral hand dimensions (length and breadth) and hand index were significantly different in men and women from north and south India [53]. Sectioning point values for hand dimensions accurately estimated sex $(80 \%$ to $89 \%)$ in that study. However, hand index was a poor discriminator for sex [53]. Sectioning point values for bilateral hand and foot dimensions (length and breadth) also accurately predicted sex (minimum 76\% for right hand length to maximum 91\% for right hand breadth) in a study among Rajput adults from Himachal Pradesh in north India [19]. However, sectioning point values for bilateral hand and foot indices had relatively lower accuracy in the estimation of sex in the study. Bilateral measurements of hand length and hand breadth showed significant sex difference $(p<0.05)$ in a sample of 18 to 60 years old adults from Udaipur, Rajasthan [52]. In the study, sectioning point value analysis for hand dimensions correctly estimated sex with an approximation of $80 \%( \pm 3)$. Hand breadth was a better predictor of sex than hand length in that study. The sectioning point values for hand and foot dimensions in the present study when compared with earlier reports $[19,52,53]$, had shown lower values for hand length (bilateral) and higher values for bilateral hand indices and foot dimensions (bilateral length, breadth and indices). However, sectioning point values for bilateral measurements of hand breadth were lower than two earlier studies [19,52] and higher than those reported in another study (Table 3) [53].

\section{Conclusion}

The results of the present study contributes new data from this part of the world and offer easier ways to understand sex differentials with respect to height and relative proportions of linear body dimensions. The use of sectioning point value as cut-off to estimate sex also worked effectively in the present context. The study further strengthen the value of the use of the cut-off as reported earlier [19,52,53]. In forensic science research, understanding relative proportions of body dimensions to height in adult men and women and degrees of sex differences are important. The use of sectioning point values for body 
dimensions will be an easier and effective way to estimate sex in medico-legal practices. The present study however, did not include results of height estimation from body dimensions through regression analysis. That could be an extensive report in future. The results need further research with data of children, adolescents and adults representing different populations.

\section{Acknowledgement}

The author thankfully acknowledges the help and cooperation extended by the participants and local community leaders. The present study was done under research projects of the author, sponsored by the University Grants Commission (UGC), New Delhi (Sanction Memo No. 33-442/2007 (SR), Dated April 16, 2008) and Indian Council of Medical Research (ICMR), New Delhi (Sanction Memo no-5/9/63/2008-RHN, Dated November 23, 2009). The author is grateful to the Vidyasagar University (Midnapore, West Bengal, India) authority for providing with infrastructural facilities to run the research projects.

\section{References}

1. Ozaslan A, Iscan MY, Ozaslan I, Tugcu H, Koc S (2003) Estimation of stature from body parts. Forensic Sci Int 132: 40-50.

2. Sharma VK, Garg RK, Chattopadhyay PK (1978) Calculation of stature from foot measurements: a study of Gaur Brahmins. Coll Antropol 2: 194-195.

3. Nath S (1997) Estimation of stature through hand and foot lengths among Jats of Rajasthan. Police Res Dev J QE: 20-22.

4. Nath S, Rajni, Chhibber S (1990) Reconstruction of stature from percutaneous lengths of upper and lower extremity segments among Punjabi females of Delhi. Indian J Forensic Sci 4: 171-181.

5. Anand N, Nath S (1990) Estimation of stature through percutaneous measures of the upper and lower extremities among Rajputs of Pauri Garhwal. Ind J Forensic Sci 5: 83-89.

6. Nath S, Garg R, Krishan G (1991) Estimation of stature through percutaneous measurements of upper and lower limbs among male Rajputs of Dehradun. J Indian Anthropological Soc 26: 245-249.

7. Singh TS, Phookan MN (1993) Stature and foot size in four Thai communities of Assam, India. Anthrop Anz 51: 349-355.

8. Jain P, Kaur S, Nath S (1996) Reconstruction of stature from hand and foot dimensions among male Brahmins of Kumaon (India). J Indian Acad Forensic Sci 35: 22-29.

9. Jain P, Nath, S (1997) Estimation of stature through upper and lower limb dimensions among Brahmins of Kumaon. Indian J Phys Anthropol Human Genet 20: 163-168.

10. Kanchan T, Menezes RG, Moudgil R, Kaur R, Kotian MS, et al. (2008) Stature estimation from foot dimensions. Forensic Sci Int 179: e1-e5.

11. Krishan K (2008) Determination of stature from foot and its segments in a North Indian population. Am J Forensic Med Pathol 29: 297-303.

12. Krishan K (2008) Estimation of stature from foot print and foot outline dimensions in Gujjars of North India. Forensic Sci Int 175: 93-101.

13. Sen J, Ghosh S (2008) Estimation of stature from foot length and foot breadth among the Rajbanshi: an indigenous population of North Bengal. Forensic Sci Int 181: 55.e1-55.e6.

14. Bhatnagar DP, Thapar SP, Batish MK (1984) Identification of personal height from the somatometry of the hand in Punjabi males. Forensic Sci Int 24: 137-141.

15. Jain P, Singh S, Arora P, Majumdar P, Kaur K, et al. (2006) Determination of stature using lower limb dimensions. In: Chandra R, Nath S, Janjua P, editors. Modern Trends in Forensic Science, Shree Publishers and Distributors, New Delhi, India, pp: 176-185.
16. Jasuja OP, Singh J, Jain M (1991) Estimation of stature from foot and shoe measurements by multiplication factors: A reviewed attempt. Forensic Sci Int 50: 203-215.

17. Khanapurkar S, Radke A (2012) Estimation of stature from the measurement of foot length, hand length and head length in Maharashtra region. Indian J Basic App Med Res 1: 77-85.

18. Krishan K, Kanchan $\mathrm{T}$ (2013) Foot length is a functional parameter for assessment of height. The Foot 23: 54-55.

19. Krishan K, Kanchan T, Sharma A (2011) Sex determination from hand and foot dimensions in a North Indian population. J Forensic Sci 56: 453-459.

20. Krishan K, Kanchan T, Sharma A (2012) Multiplication factor versus regression analysis in stature estimation from hand and foot dimensions. J Forensic Leg Med 19: 211-214.

21. Krishan K, Sharma A (2007) Estimation of stature from dimensions of hands and feet in a North Indian population. J Forensic Leg Med 14: 327-332.

22. Patel SM, Shah GV, Patel SV (2007) Estimation of height from measurements of foot length in Gujarat region. J Anat Soc India 56: 25-27.

23. Qamra SR, Deodhar SD, Jit I (1986) A metric study of feet of north-west Indians and its relationship to body height and weight. Int J Physiol Anthopol Hum Gen 12: 131-138.

24. Qamra SR, Jit I, Deodhar SD (1980) A model for construction of height from foot measurements in an adult population of North-West India. Ind J Med Res 71: 77-83.

25. Rani M, Tyagi AK, Ranga VK, Rani Y, Murari A (2011) Stature estimates from foot dimensions. J Punjab Acad Forensic Med Toxicol 11: 26-30.

26. Rastogi P, Nagesh KR, Yoganarasimha K (2008) Estimation of stature from hand dimensions of North and South Indians. Legal Medicine 10: 185-189.

27. Saxena SK (1984) A study of correlations and estimation of stature from hand length, hand breadth and sole length. Anthropol Anz 42: 271-276.

28. Singh JP, Rani Y, Meena MC, Murari A, Sharma GK (2013) Stature estimation from the dimensions of foot in males. Ínsanbil Derg 2: 15-20.

29. Abdel-Malek AK, Ahmed AM, el-Sharkawi SA, el-Hamid NA (1990) Prediction of statue from hand measurements. Forensic Sci Int 43: 181-187.

30. Agnihotri AK, Agnihotri S, Jeebun N, Googoolye K (2008) Prediction of stature using hand dimensions. J Forensic Leg Med 15: 479-482.

31. Agnihotri AK, Purwar B, Googoolybe K, Agnihotri S, Jeebun N (2007) Estimation of stature by foot length. J Forensic Leg Med 14: 279-283.

32. Agnihotri AK, Shukla S, Purwar B (2007) Determination of sex from foot measurements. Internet J Forensic Sci 2: 7765.

33. Bob-Manuel I, Didia B (2008) Sexual dimorphism in foot dimensions among adult Nigerians. Internet J Biol Anthropol 3: 3768.

34. Barnabas D, Elupko A (2008) Sexual dimorphism in hand and foot length, indices, stature-ratio and relationship to height in Nigerians. Internet J Forensic Sci 3: 3916.

35. Ibeachu PC, Abu EC, Didia BC (2011) Anthropometric sexual dimorphism of hand length, breadth and hand indices of University of Port-Harcourt students. Asian J Med Sci 3: 146-150.

36. Ilayperuma I, Nanayakkara G, Palahepitiya N (2009) Prediction of personal stature based on the hand length. Galle Med J 14: 14-18.

37. Ozden H, Balci Y, Demrustu C, Turgut A, Ertugrul M (2005) Stature and sex estimate using foot and shoe dimensions. Forensic Sci Int 147: 181-184.

38. Sanli SG, Kizilkanat ED, Boyan N, Ozsahin ET, Bozkir MG, et al. (2005) Stature estimation based on hand length and foot length. Clin Anat 18: 589-596.

39. Zeybek G, Ergur I, Demiroglu Z (2008) Stature and gender estimation using foot measurements. Forensic Sci Int 181: 54.e1-54.e5.

40. Giles E, Vallandigham PH (1991) Height estimation from foot and shoeprints length. J Forensic Sci 36: 1134-1151. 
Citation: Datta Banik S (2016) Interrelationships between Height and Selected Linear Body Dimensions and Estimation of Sex in NepaliSpeaking Adults from Naxalbari, Darjeeling. J Forensic Res 7: 354. doi:10.4172/2157-7145.1000354

Page 8 of 8

41. Bhavna, Khurana K, Singh S, Kaur K, Nath S (2006) Prediction of stature through the lower limb dimensions among Brahmin and Jat females of Sampla, Haryana. In: Chandra R, Nath S, Janjua P, editors. Modern Trends in Forensic Science, Shree Publishers and Distributors, New Delhi, India, pp. 112-119.

42. Bhavna, Nath S (2007) Estimation of stature on the basis of measurements of the lower limb. Anthropologist 3: 219-222.

43. Duggal N, Nath S (1986) Estimation of stature using percutaneous length of radius, ulna and tibia among Lodhas and Mundas of District Midnapore, West Bengal. Anthropologie 24: 23-27.

44. Nath S, Krishan G (1990) Determination of stature using percutaneous measurements of upper and lower limb bones among Hindu (Baniya) females of Delhi. J Anthropol Surv India 39: 151-156.

45. Sarojini Devi H, Das BK, Pumabati S, Singh D, Jayashree D (2006) Estimation of stature from upper arm length among Marings of Manipur. Indian Med J 100: 271-273.

46. Akhlaghi M, Hajibeygi M, Zamani N, Moradi B (2012) Estimation of stature from upper limb anthropometry in Iranian population. J Forensic Leg Med 19: 280-284.

47. Ahmed AA (2013) Estimation of stature from the upper limb measurements of Sudanese adults. Forensic Sci Int 228: 178.e1-178.e7.

48. Jarzem PF, Gledhill RB (1993) Predicting height from arm measurements. J Pediatr Orthop 13: 761-765.

49. Han TS, Lean ME (1996) Lower leg length as an index of stature in adults Int J Obes Relat Metab Disord 20: 21-27.

50. Ozaslan A, Koc S, Ozaslan I, Tuğcu H (2006) Estimation of stature from upper extremity. Milit Med 171: 288-291.

51. Agnihotri A, Purwar B, Jeebun N (2005) Determination of sex by hand dimensions. Internet J Forensic Sci 1: 9047.

52. Dey S, Kapoor AK (2015) Sex determination from hand dimensions for forensic identification. Int J Res Med Sci 3: 1466-1472.

53. Kanchan T, Rastogi P (2009) Sex determination from hand dimensions of North and South Indians. J Forensic Sci 54: 546-550.
54. Moudgil R, Kaur R, Menezes RG, Kanchan T, Garg RK (2008) Foot index: is it a tool for sex determination? J Forensic Leg Med 15: 223-226.

55. Cochran WG (1977) Sampling techniques. John Wiley and Co, New York, USA.

56. Risley HH (1891) Tribes and Caste of Bengal, Firma KLM Ltd, Kolkata, India.

57. Bhattacharjee P (2015) Nutritional status and body composition of children and adolescents among Mech and Limbu communities of Darjeeling and Jalpaiguri Districts in West Bengal-Comparative study. Ph.D thesis: Vidyasagar University, Midnapore, West Bengal, India.

58. Banik SD (2014) Body mass index and blood pressure among men of three ethnic groups of Darjeeling, West Bengal, India. Ecol Food Nutr 53: 256-272.

59. Banik SD, Bose K, Bisai S, Jana A, Das S, et al. (2007) Undernutrition in adult Dhimals of Naxalbari West Bengal: Comparison with other tribes of Eastern India. Food Nutr Bull 28: 348-352.

60. Ulijaszek S, Kerr D (1999) Anthropometric measurement error and the assessment of nutritional status. Br J Nutr 82: 165-177.

61. Lohman TG, Roche AF, Martorell R (1988) Anthropometric standardization reference Manual. Human Kinetics Books, Champagne, Illinois, USA.

62. WHO (1995) Physical status: The use and interpretation of anthropometry. Report of a WHO Expert Committee. WHO Technical Report Series 854, World Health Organization, Geneva, Switzerland.

63. Bogin B, Varela-Silva MI (2010) Leg length, body proportion, and health: A review with a Note on Beauty. Int J Environ Res Public Health 7: 1047-1075.

64. MacLaughlin SM, Bruce MF (1986) The sciatic notch/acetabular index as a discriminator of sex in European skeletal remains. J Forensic Sci 31: 1380-1390. 